\title{
TERAPI MUROTTAL SEBAGAI UPAYA MENURUNKAN KECEMASAN DAN TEKANAN DARAH PADA IBU HAMIL DENGAN PREEKLAMPSIA : LITERATURE REVIEW DILENGKAPI STUDI KASUS
}

\author{
Diki Retno Yuliani ${ }^{1)}$ Melyana Nurul Widyawati ${ }^{2)}$ Dyah Lustika Rahayu ${ }^{3)}$ \\ Anita Widiastuti ${ }^{2)}$ Rusmini $^{2)}$ \\ E-mail address: dikiretnoyuliani@gmail.com
}

\begin{abstract}
The maternal mortality rate (MMR) in Indonesia is far from being the target of sustainable development goal's (SDG's), with one of the dominant causes being hypertension in pregnancy (HDK) such as preeclampsia. Pregnant women with preeclampsia are prone to experience anxiety, which if left untreated will have an effect on the welfare of the mother and baby. Anxiety can also cause blood pressure to raise. One relaxation technique to reduce anxiety and blood pressure is with murottal therapy. The purpose of this study was to determine the effect of murottal therapy in reducing anxiety and blood pressure in pregnant women with preeclampsia and to find out how to apply it to the case study.

The research design used is literature review and case study. Samples for literature review were obtained from electronic databases, namely Google Scholar of 6 articles about the theme of Murottal and anxiety therapy (5 national and 1 international) and 8 articles on the theme of murottal therapy and blood pressure. Samples for case studies of 2 pregnant women with preeclampsia.

The results obtained from the literature review include a decrease in anxiety scores before and after treatment with a mean reduction in anxiety scores 6,297 , there is an effect of murottal therapy on blood pressure or there is a difference in blood pressure before and after getting treatment, the average decrease in mean systole 12,188 and average mean decrease in mean diastolic 6,233. Whereas the results obtained from the case study include risk factors for preeclampsia in the respondent is a history of hypertension, obesity and primipara; lack of knowledge or information and lack of optimal application of therapeutic communication is a factor that aggravates anxiety and; anxiety scores dropped after receiving murottal therapy and blood pressure also fell relative.
\end{abstract}

Keywords: murottal; anxiety; preeclampsia

1) Students Of Midwifery Applied Masters Study Program,

Poltekkes Kemenkes Semarang

${ }^{2)}$ Lecturer, Poltekkes Kemenkes Semarang

${ }^{3)}$ Midwife Of Rawalo Health Center, Puskesmas Rawalo

\section{Pendahuluan}

Angka kematian ibu (AKI) merupakan salah satu indikator dalam menilai derajad kesehatan suatu negara. Tahun 2015 AKI di Indonesia sejumlah 305 kasus per 100.000 kelahiran hidup, turun jika dibandingkan dengan AKI tahun 2012 yaitu 359 kasus per 100.000 kelahiran hidup (KEMENKES, 2016). Walaupun mengalami penurunan, namun AKI tersebut masih sangat jauh dari pencapaian target sustainable development goals (SDG's) di tahun 
2030, yaitu 30 kasus per 100.000 kelahiran hidup di tahun 2030 (KEMENKES, 2015).

Hipertensi dalam kehamilan (HDK) merupakan salah satu penyebab dominan kematian ibu di Indonesia yang memiliki pola meningkat dari tahun ke tahun. Tahun 2010 AKI yang disebabkan oleh HDK 21,5\%, tahun $201124,7 \%$, tahun 2012 26,9\% dan tahun 2013 27,1 \% (KEMENKES, 2016). Preeklampsia merupakan salah satu jenis HDK yang terjadi setelah usia kehamilan 20 minggu disertai dengan adanya gangguan organ. Adapun gangguan organ yang dapat terjadi meliputi protein urin, trombositopeni, gangguan ginjal, gangguan liver, gangguan neurologis, edema paru dan gangguan sirkulasi uteroplasenta (Noroyono and $\mathrm{dkk}$, 2016). Tidak hanya di Indonesia saja, pre eklampsia juga menjadi salah satu dari tiga penyebab dominan kematian ibu di dunia (Asghari et al., 2016).

Ibu hamil dengan preeklampsia dapat mengalami stres yang lebih berat dibandingkan dengan ibu hamil tanpa preeklampsia (Isworo et al., 2012). Menurut penelitian ada perbedaan antara skor kecemasan ibu hamil normal dengan ibu hamil dengan preeklampsia, dimana rerata skor kecemasan ibu hamil normal adalah 18,50 sedangkan pada ibu hamil dengan preeklampsia adalah 30,45 (Serudji et al., 2017). Menurut penelitian lain, ibu hamil dengan kecemasan akan meningkatkan kejadian preeklampsia sampai 7,84 kali lipat, jika kecemasan dialami oleh ibu dengan preeklampsia tentu akan semakin memperberat kondisi preeklampsianya. Kecemasan / stres akibat preeklampsia pada ibu hamil jika tidak ditangani akan berdampak pada kesejahteraan ibu dan bayi (Isworo et al., 2012). Dampak kecemasan pada ibu diantaranya dapat menyebabkan spasme pembuluh darah memburuk sehingga terjadi kenaikan tekanan darah (Trisiani, 2016)

Al-Qur'an merupakan salah satu metode pengobatan yang memiliki semua jenis program dan data yang diperlukan untuk mengobati berbagai macam gangguan pada sel tubuh. Murottal (mendengarkan bacaan AlQur'an adalah salah satu metode penyembuhan dengan menggunakan Al-Qur'an. Mendengarkan murottal Al-Qur'an dapat memberikan pengaruh terhadap kecerdasan emosional, (EQ) kecerdasan intelektual (IQ), serta kecerdasan spiritual (SQ) seseorang. Mendengarkan murottal akan menimbulkan efek tenang dan rileks pada diri seseorang, sehingga akan turut memberikan kontribusi dalam penurunan tekanan darah (Kartini et al., 2017). Perasaan rileks dari mendengarkan murottal juga dapat mempengaruhi kecemasan, seperti laporan dari salah satu hasil penelitian bahwa, ada perbedaan rerata skor kecemasan sebelum dan sesudah mendengarkan murottal (Handayani et al., 2014).

Telah banyak penelitian yang dilakukan terkait dengan tema pengaruh terapi murottal terhadap kecemasan dan tekanan darah. Hal tersebut merupakan salah satu upaya untuk mengembangkan teknik pengobatan nonfarmakologis sebagai pendamping pengobatan farmakologis dalam dunia kesehatan. Salah satunya adalah penerapan terapi murottal untuk menurunkan kecemasan dan tekanan darah pada ibu hamil dengan preeklmapsia sehingga kesejahteraan ibu dan janin terjamin. Berdasarkan 
latar belakang tersebut penulis tertarik untuk melaksanakan literture review pada beberapa jurnal terdahulu dengan tema terapi murottal sebagai upaya menurunkan kecemasan dan mengontrol tekanan darah pada ibu dengan preeklmapsia. Selain itu, penulis juga akan menyertakan studi kasus dengan tema yang sama, untuk memperkuat kajian literature review.

Tujuan penelitian ini adalah untuk mengetahui pengaruh terapi murottal untuk menurunkan kecemasan dan tekanan darah pada ibu hamil dengan preeklampsia dan untuk mengetahui bagaimana penerapan terapi murottal terhadap kecemasan dan tekanan darah ibu hamil dengan preeklampsia pada studi kasus.

\section{Metode Penelitian}

Strategi yang dilakukan adalah dengan melalui pencarian artikel dengan tema yang sesuai. Pencarian artikel dilakukan pada artikel-artikel jurnal yang telah dipublikasi melalui database elektronik yaitu google scholar. Pada awalnya kata kunci yang digunakan adalah "murottal", "cemas", "tekanan darah" dan "preeklampsia", namun hasil yang diperoleh tidak memadai. Pada kata kunci "murottal, cemas, preeklampsia", tidak ditemukan artikel yang sesuai, sedangkan dengan kata kunci "murottal, tekanan darah, preeklampsia" hanya ditemukan 1 artikel. Kemudian penulis sedikit memperluas kata kunci yang dipakai, untuk "murottal, cemas, preeklampsia", kata preeklampsia digantikan dengan hamil, bersalin, nifas, pregnancy, labor dan postpartum dikarenakan pada masa itulah preeklmapsia dapat timbul. Sedangkan untuk kata kunci "murottal, tekanan darah, preeklmapsia", kata preeklampsia diganti dengan hipertensi. Dari kata kunci "murottal, cemas, hamil/bersalin/nifas/ pregnancy /labor/postpartum" diperoleh artikel hamil 2, artikel bersalin 3, artikel labor 1, dan artikel nifas, pregnancy, postpartum tidak ada. Sedangkan dari kata kunci "murottal, tekanan darah, hipertensi", diperoleh 9 artikel, namun yang mempunyai artikel lengkap dari abstrak sampai hasil penelitian hanya 7. Sehingga total artikel untuk kata kunci "murottal, cemas" 6 artikel (5 nasional dan 1 internasional) serta untuk kata kunci "murottal, tekanan darah" 8 artikel, yang kemudian akan dianalisis.

Sedangkan untuk studi kasus desain penelitian yang digunakan adalah penelitian deskriptif dengan mengobservasi skor kecemasan responden sebelum dan sesudah diberikan terapi murottal. Penelitian dilaksanakan di Wilayah Kerja Puskesmas Rawalo Kabupaten Banyumas Provinsi Jawa Tengah yaitu di Desa Sanggreman dan Tambaknegara, pada minggu ke 2 sampai minggu ke 3 Juli 2018. Sampel studi kasus sejumlah 2 orang responden yang memenuhi kriteria inklusi dan eksklusi.

Alur studi kasus yang dilalui meliputi penyusunan proposal; mencari responden sesuai kriteria inklusi dan eksklusi; menjelaskan tujuan dan menanyakan kesediaan menjadi responden; melakukan pengkajian karakteristik responden melalui wawancara termasuk tentang faktor risiko preeklampsia; pengisian kuesioner kecemasan oleh responden, pengukuran tekanan darah (TD) dan observasi keadaan umum pasien; melaksanakan terapi murottal selama 15 menit sesuai SOP; mengajarkan ibu 
untuk mendengarkan murottal minimal 1 kali / hari selama 7 hari; pengisian kuesioner kecemasan oleh responden pada hari ke 7 , pengukuran TD dan wawancara terkait kesan responden setelah mendapatkan terapi murottal; analis data serta penyusunan laporan. Instrumen penelitian yang digunkan adalah MP3 player, headphone atau headset dan kuesioner modifikasi TMAS (Taylor Manifest Anxiety Scale). Analisa data meliputi editing data, koding data, kemudian data dari 2 sampel akan di analisis bagaimana perubahan skor kecemasan dan tekanan darah sebelum dan sesudah di berikan murottal, serta akan dijelaskan kesan pasien setelah mendapatkan terapi murottal.

T-MAS terdiri dari 50 pertanyaan yang merupakan instrumen untuk mengetahui keadaan kecemasan pada seseorang yang telah terstandar dan dapat diterima secara internasional. Jika menjawab "ya" sebanyak 25 pernyataan atau lebih dinyatakan cemas, sedangkan jika menjawab "ya" kurang dari 25 dinyatakan tidak cemas.

\section{Hasil Dan Pembahasan}

\section{Literature review}

Dari tabel 1 dapat kita lihat bahwa dari 6 artikel yang berkaitan dengan tema pengaruh terapi murottal terhadap kecemasan ibu hamil preeklampsia, kesemuanya menggunakan desain pretest posttest namun tidak ada yang menggunakan kelompok kontrol. Keenam artikel juga menyatakan bahwa terdapat penurunan skor kecemasan dari pretest ke posttest (ada pengaruh murottal terhadap kecemasan). Pada satu artikel, peneliti mengkombinasikan terapi murottal dengan relaksasi nafas dalam, sedangkan 5 artikel yang lain hanya memberikan intervensi terapi murottal saja.

Empat artikel menghitung rata-rata penurunan skor kecemasan sebelum dan sesudah perlakuan dengan nilai mean tertinggi 9,938 dan mean terendah 2,8, sedangkan jika dirata-rata dari keempat artikel mean penurunan skor kecemasan adalah 6,297(Handayani et al., 2014, Karyati, 2016, Nugraheni and Romdiyah, 2018, Wulansari, 2017). Satu artikel melaporkan bahwa mayoritas tingkat kecemasan pretest adalah sedang, dan pada posttest mayoritas tingkat kecemasan berubah menjadi ringan (Deswita and Wahyuni, 2013).

Tabel 1 literature review dengan tema pengaruh terapi murottal terhadap kecemasan pada ibu hamil preeklampsia (kata kunci : "murotttal, cemas, hamil/bersalin")

N Konten Artikel

\begin{tabular}{ll} 
o & \\
\hline & Judul : Pengaruh Terapi Murottal Al-
\end{tabular}

Qur'an Untuk Penurunan Nyeri

Persalinan Dan Kecemasan Pada Ibu

Bersalin Kala I Fase Aktif

Penulis : Rohmi Handayani, Dyah Fajarsari, Dwi Retno Trisna Asih dan Dewi Naeni Rohmah

Publikasi : Bidan Prada : Jurnal Ilmiah Kebidanan (2014)

Desain Penelitian : Metode preeksperimen dengan rancangan one group pretest and posttest design

Sampel : 42 ibu bersalin normal kala I fase aktif primigravida dengan teknik sampling consecutive sampling. Tidak ada kelompok kontrol

Perlakuan : Diberikan terapi murottal Prosedur Penilaian : Diukur intensitas nyeri dan kecemasan sebelum dan sesudah diberikan terapi murottal.

Temuan : Mean intensitas nyeri pretest 6,57, dan mean posttest 4,93. Ada perbedaan rerata penurunan intensitas nyeri persalinan kala I fase aktif 
sebelum dan sesudah terapi murottal. Mean kecemasan pretest 26,67, dan mean posttest 20,52. Ada perbedaan rerata penurunan tingkat kecemasan sebelum dan sesudah dilakukan terapi murottal (Handayani et al., 2014)

2 Judul : Aplikasi Terapi Murotal AlQur'an Dan Komunikasi TerapeutikSebagai Upaya Menurunkan Tingkat Kecemasan Persalinan Peneliti : Sri Karyati

Publikasi : The 4 th Univesity Research Coloquium (2016)

Desain Penelitian : Quasy experimentdengan metode pretest and posttest nonequivalent control group.

Sampel : $20 \mathrm{ibu}$ bersalin kala I fase aktif dengan teknik sampling purposive random sampling. Di bagi dua kelompok yaitu teknik murottal dan komunikasi terapeutik. Tidak ada kelompok kontrol

Perlakuan : Diberikan terapi murottal dan komunikasi terapeutik

Prosedur Penilaian : Diukur tingkat kecemasan sebelum dan sesudah diberikan terapi murottal dan komuniasi terapeutik

Temuan :Mean skor kecemasan kelompok murotal pretest 21,8 dan mean posttest 15,5 (penurunan 6,3). Pada kelompok komunikasi, mean pretest 25,6 dan mean I 19,6 (penurunan 3,0). Tidak ada perbedaan bermakna penurunankecemasan persalinan dari prestest ke posttest pada kelompok murotal al Qur'an dengan kelompok komunikasi terapeutik (Karyati, 2016).

3 Judul : Perbedaan Perlakuan Senam Hamil Dan Terapi Murotal Terhadap Penurunan Tingkat Kecemasan Ibu Hamil Trimester III

Peneliti : Nazilla Nugraheni dan Romdiyah

Publikasi : Jurnal Penelitian dan Pengabdian kepada Masyarakat UNSIQ (2018)

Desain Penelitian : Metode Quasy ekperiment dengan desain non equivalent prettest and posttest dan pendekatan Cross sectional

Sampel : 34 ibu hamil trimster III dengan teknik sampling purposive sampling. Dibagi 2 kelompok yaitu kelompok senam hamil dan kelompok terapi murottal.Tidak ada kelompok kontrol

Perlakuan : Diberikan terapi murottal dan senam hamil

Prosedur Penilaian : Diukur tingkat kecemasan sebelum dan sesudah diberikan terapi murottal dan senam hamil

Temuan :Terapi murotal lebih efektif menurunkan kecemasan dengan selisih rerata penurunan point sebelum dan sesudah perlakuan adalah 2,8 dan $\mathrm{P}$ value 0,01 . Hal ini menunjukkan bahwa terdapat perbedaan antara kelompok senam hamil dan kelompok murotal (Nugraheni and Romdiyah, 2018).

4 Judul : Pengaruh Terapi Murottal Terhadap Perubahan Skor Kecemasan Ibu Bersalin Kala I Fase Laten Di RS Nur Hidayah Bantul

Peneliti : Arista Wulansari

Publikasi : Skripsi (2017)

Desain Penelitian : Metode Quasi Experimen dengan pendekatan One Group Pre test and Post test Without Control Group Design.

Sampel : $32 \mathrm{ibu}$ bersalin kala I fase laten dengan teknik sampling purposive sampling. Tidak ada kelompok kontrol

Perlakuan : Diberikan Terapi murottal menggunakan QS. Ar-Rahman (1-78 ayat) selama 25 enit

Prosedur Penilaian : Diukur tingkat kecemasan sebelum dan sesudah diberikan terapi murottal

Temuan :Mean skor kecemasan pretest 48,84 dan mean posttest 38,91. mean perubahan skor kecemasan pretest dan posttest 9,938. Diperoleh index perbedaan (t) hitung sebesar 5,389 dengan nilai signifikansi (p) sebesar 0,001. Terdapat pengaruh terapi murottal terhadap perubahan skor kecemasan ibu bersalin kala I fase laten (Wulansari, 2017). 


\section{Judul : Pengaruh Terapi Murotal Terhadap Tingkat KecemasanMenghadapi Persalinan Pada Ibu Hamil di Wilayah Kerja \\ Puskesmas Andalas \\ Peneliti : Riza Wahyuni dan Deswita \\ Publikasi : Ners Jurnal Keperawatan (2013)}

Desain Penelitian: Quasy eksperiment dengan pendekatan one group

pretest-posttest:

Sampel : 12 ibu hamil trimester III dengan teknik sampling purposive sampling.Tidak ada kelompok kontrol

Perlakuan : diberikan terapi murotal sebanyak tiga kali

Prosedur Penilaian : Diukur tingkat kecemasan sebelum dan sesudah diberikan terapi murottal

Temuan :Tingkat kecemasan pretest mayoritas sedang $(66,7 \%)$ sedangkan tingkat kecemasan post test mayoritas ringan $(41,7 \%)$. Ada pengaruh terapi murotal terhadap tingkat kecemasan ibu hamil trimester ketiga dalam menghadapi persalinan (Deswita and Wahyuni, 2013)

6 Judul : The Influence Of Combination Murottal Holy Qur'an And

Deep Breath Relaxation To Face Anxiety A Labor

Peneliti : Fauzia Laili dan Endang Wartini

Publikasi : The 1st International Conference Ikatan PerawatMaternitas East Java 2017

Desain Penelitian : quantitative approach design by one group pre-post test

Sampel : 16 ibu hamil trimester III dengan teknik sampling purposive sampling. Tidak ada kelompok kontrol

Perlakuan : Diberikan kombinasi murottal Al-Qur'an dengan relaksasi nafas dalam

Prosedur Penilaian : Pengukuran kecemasan sebelum dan sesudah perlakuan

Temuan :Ada pengaruh kombinasi murottal Al- Qur'an dan relaksasi nafas dalamuntuk menghadapi kecemasan karena kehamilan (Laili and Wartini, 2017).

Tabel 2 literature review dengan tema pengaruh terapi murottal terhadap tekanan darah pada ibu hamil preeklampsia (kata kunci : "murotttal, tekanan darah, preeklampsia /hipertensi”)

\begin{tabular}{l}
\hline N Konten Artikel \\
o \\
\hline I Judul : Pengaruh Mendengarkan Murottal \\
TerhadapPenurunan Tekanan Darah Pada \\
Ibu HamilPreeklamsi Di Rsia Pku \\
MuhammadiyahTangerang \\
Peneliti : Kartini,Yudhia Fratidhina dan \\
Heni Kurniyati \\
Publikasi : JKFT (2016) \\
Desain Penelitian : Quasi Experiment, \\
dengan rancangan \\
one group pretest dan posttest. \\
Sampel : 30 ibu hamil trimester II yang
\end{tabular}

Sampel : 30 ibu hamil trimester II yang mengalami hipertensi, dengan teknik sampling total sampling. Dibagi 2 kelompok yaitu kelompok intervensi dan kelompok kontrol

Perlakuan : kelompok intervensi : Mendengarkan murottal. kelompok kontrol : Tidak mendengarkan murottal

Prosedur Penilaian : Mengukur sistolik dan diastolik sebelum dan sesudah terapi murottal

Temuan :Untuk kelompok intervensi mean pretest (sistole 165, diastole 95) mean posttest (sistole 152, diastole 85). Untuk kelompok kontrol mean pretest (sistole 161, diastole 89) mean posttest (sistole 161 diastole 89). Ada perbedaan rata-rata antara tekanan darah diastolik posttest kelompok intervensi dan kelompok kontrol (Kartini et al., 2016).

2 Judul : Pengaruh Teknik Relaksasi Benson Dan Murottal Al-Qur'an

Terhadap Tekanan Darah Pada PenderitaHipertensi Primer

Peneliti : Laras Pratiwi, Yesi Hasneli dan Juniar Ernawaty

Publikasi : Jurnal Online Mahasiswa 
(JOM) Program Studi Ilmu Keperawatan Universitas Riau (2015)

DesainPenelitian : Quasi experiment dengan

pendekatan nonequivalent control group

Sampel : 30 pasien yang menderita hipertensiPrimer. Dibagi menjadi 2 kelompok yaitu kelompok intervensi dan kelompok kontrol

Perlakuan : Kelompok intervensi : Melaksanakan teknik relaksasi benson dan mendengarkan murottal Al- Qur'an surat Ar-rahman selama \pm 10 menit, kelompok kontrol : Tidak melaksanakan relaksasi benson dan tidak mendengarkan murottal

Prosedur Penilaian : Mengukur TD sebelum dan sesudah relaksasi benson dan murottal

Temuan :Untuk kelompok intervensi mean pretest (sistole 165,53, diastole 91,60) mean posttest (sistole 147,93, diastole 87,27). Untuk kelompok kontrol mean pretest (sistole 154,27, diastole 90,13) mean posttest (sistole 155,80, diastole 90,67). Ada perbedaan yang signifikan rata-rata tekanan darah sistol diastol setelah diberikan teknik relaksasi bensondan murottal Al-Qur'an pada kelompokeksperimen dan kelompok kontrol. Teknik relaksasi benson dan murottal Al-Qur'an efektif dalam menurunkan TD pada pasien hipertensi primer (Pratiwi et al., 2015).

3 Judul : Pengaruh Terapi Murottal AlQur'an TerhadapTekanandarah Pada Pasien Hipertensidi RuangCempaka RSUD Dr. H. Soewondo Kendal

Peneliti : Dwi Nur Aini, Priharyanti Wulandari dan Sri Puji Astuti

Publikasi : Jurnal Ners Widya Husada Semarang (2018)

Desain Penelitian : quasyexperiment dengan desain pre andpost test without control

Sampel : 26 pasien hipertensi dengan teknik sampling purposive sampling. Tidak ada kelompok kontrol

Perlakuan : Memberikan terapi murottalkepada responden selama \pm 15menit selama 1 minggu (7hari)

Prosedur Penilaian : Mengukur TD pretest (sebelum perlakuan) dan posttest
(5-10 menit setelah perlakuan)

Temuan :Pretest mayoritas responden dengan hipertensi berat $(57,7 \%)$ dan pada posttest mayoritas reponden tanpa hipertensi / normal (53,8\%). Ada pengaruh yang signifikan antara terapi murottal AlQur'an terhadap penurunan TD pada penderitahipertensi (Aini et al., 2018).

4 Judul : The Effect of The Murottal AlQur'an Therapy on Blood Pressureof Pre Operative Cataract Patients with Hypertension in TulipInpatient Ward of $d r$. Soebandi Hospital, Jember

Peneliti : Siswoyo, Sulis Setyowati dan Muhamad Zulfatul A'la.

Publikasi : e-Jurnal Pustaka Kesehatan ( 2017)

Desain Penelitian : quasi eksperiment dengan pretestposttest with control group design

Sampel : 30 pasien pre operasi katarak dengan hipertensi dengan teknik sampling quota sampling. Dibagi menjadi kelompok intervensi dan kelompok kontrol

Perlakuan : kelompok intervensi : Pasien diberikan terapi murottal Al-Qur'an sebanyak 3 kali dalam sehari (saat pasien opname, jam 19.00 wib dan 1 jam pre operasi), kelompok kontrol : Tidak diberikan terapi murottal

Prosedur Penilaian : Pengukuran TD pretest sebelum intervensi. Observasi TD pasien 15 menit setelah terapi selama menjalani perawatan.Pengambilan data posttest pada pagi hari sebelumdilaksanakan operasi katarak.

Temuan :Untuk kelompok intervensi Tekanan sistol diastol pretest mayoritas hipertensi, sedangkan tekanan sistole diastole posttest mayoritas pre hipertensi. Untuk kelompok kontrol tekanan sistol pretest prehipertensi dan pada posttest tetap pada prehipertensi, sedangkan tekanan diastole pretest hipertensi dan pada posttest tetap pada hipertensi.Ada pengaruh terapi murottal al-qur'an terhadap tekanan darah pasien pre operasi katarak denganhipertensi (Siswoyo et al., 2017).

5 Judul : Pengaruh Terapi Suara Terhadap Tekanan DarahPenderita Hipertensi Di Posyandu LansiaSedap Malam Padukuhan Gandok, Sleman D.I. Yogyakarta 
Peneliti : Rahadian Eko Yudistiro

Publikasi : Skripsi (2017)

Desain Penelitian : Desain dalam penelitianini adalah pretest-posttest control groupdesign

Sampel : 21 responden dibagi 3 kelompok, kelompok musik instrumental, murottal dan kontrol. Teknik sampling probability sampling dengan teknikrandom sampling

Perlakuan : kelompok intervensi : Mendapatkan terapi suara, dimana tiga kali perlakuan dengan jeda satu hari tanpa perlakuan, selama enam hari. Kelompokn kontrol : Tidak mendapatkan perlakuan terapi suara

Prosedur Penilaian : Pengukuran tekanan darah respondensebelum dan sesudah dilakukan perlakuanterapi suara

Temuan :Mean sistole pada kelompok instrumental turun $22 \mathrm{mmHg}$ (173 menjadi $151 \mathrm{mHg}$ ), pada kelompok murottal turun $11 \mathrm{mmHg}$ (153 menjadi $142 \mathrm{mmHg}$ ), dan padakelompok kontrol naik $2 \mathrm{mmHg}$ (151 menjadi $153 \mathrm{mmHg}$ ). Mean Diastole pada kelompok instrumental turun $15 \mathrm{mmHg}$ (107 menjadi $92 \mathrm{mmHg}$ ), pada kelompok murottal turun $9 \mathrm{mmHg}$ (96 menjadi 87 $\mathrm{mmHg}$ ), dan pada kelompok kontrol naik 2 mmHg (96 menjadi 98 mmHg).Ada pengaruh terapi suara terhadap tekanan darah pasien hipertensi sebelum dan sesudah perlakuan.Terapi suara, baik instrumental maupun murottal dapat menurunkan tekanan darah secara signifikan, namun penurunan tekanan darah kelompok instrumental lebih besar dibanding dengan kelompok murottal (Yudistiro, 2017).

6 Judul : Efektivitas Kombinasi Senam Aerobik Low Impact Dan Terapi Murottal Quran Terhadap Perubahan Tekanan Darah Pada Lansia Hipertensi Di UPT Panti Sosial Tresna Werdha Mulia Dharma Kabupaten Kubu Raya

Peneliti : Andri D. Hernawan, Dedi Alamsyah dan Meti Maya Sari

Publikasi : Jurnal Mahasiswa Dan Penelitian Kesehatan (2017)

Desain Penelitian : Eksperimen semu dengan desain penelitian one group pretest post- test desain

Sampel : 21 lansia hipertensi dengan teknik sampling total sampling. Tidak ada kelompok kontrol

Perlakuan : Mejalani senam aerobic low impac dan mendengarkan murottal AlQuran surah Ar-Rahman

Prosedur Penilaian : mengukur tekanan darah pretest (30 menit sebelum senam) dan posttest (seminggu setelah perlakukan) Temuan :Untuk mean sistol pretest 148,57 dan mean postest 140, sedangkan mean diastol pretest 83,81 dan mean posttest 77,14 .

ada perbedaan bermakna tekanan darah sistolik dan diastolik sebelum dan sesudah melakunan senam aerobik low impact dan terapi murottal Quran (Hernawan et al., 2017).

7 Judul: Judul :Therapy Murottal ArRahman Letter Of Changes In Blood Pressure In Hypertension Patients In RSUDZA Banda Aceh

Peneliti : Erlina dan Setio Budi Raharjo Publikasi : Jurnal Ilmiah Mahasiswa Fakultas Keperawatan (2016)

Desain Penelitian : Pra-eksperimen dengan desain one group pretes-posttes design

Sampel : 20 pasien hipertensi dengan teknik sampling accidental sampling.Tidak ada kelompok kontrol

Perlakuan : Diberikan terapi murottal surah Ar-Rahman

Prosedur Penilaian : Mengukur tekanan darah sebelum dan sesudah perlakuan

Temuan :Untuk sistol mean pretest 149,5 dan mean posttest 139, sedangkan untuk diatole mean pretest 95 dan mean posttest 89. Ada perbedaan sebelum dan sesudah pemberian terapi murottal surat ArRahman terhadap perubahan tekanan darah sistol dan diastol pada pasien hipertensi (Erlina and Raharjo, 2016)

8 Judul : Pengaruh Terapi Murottal Surah Ar-Rahman Terhadap Perubahan TD Pada Lansia Penderita Hipertensi Di Posyandu Lansia Kenanga Wilayah Kerja UPK Puskesmas Siantan Hulu Kec. Pontianak Utara

Peneliti : Ika Wahyu Widyastuti

Publikasi : ProNers (2015)

Desain Penelitian : Quasi-eksperimental denganrancangan one group pretest posttest design tanpa adanya kelompok 
kontrol

Sampel : 24 lansia hipertensi dengan teknik Non Probability Sampling dan metode PurposiveSampling.Tidak ada kelompok kontrol

Perlakuan : Diberikan terapo murottal surah Ar-Rahman

Prosedur Penilaian : Pengukuran tekanan darah sebelum dan sesudah perlakuan

Temuan :Untuk sistol mean pretest 151,88 dan mean posttest 139,42. Sedangkan untuk diastol mean pretest 90 dan mean posttest 85 . Ada pengaruh terapi murottal surah Ar-Rahman terhadap tekanan darahsebelum dan setelah intervensi sehingga terapi murottal surah Ar-Rahman efektif untuk menurunkan tekanan darah padalansia (Widyastuti, 2015).

Kecemasan adalah suatu kondisi kejiwaan yang penuh dengan kekhawatiran terhadap apa yang mungkin terjadi (Deswita and Wahyuni, 2013). Kepustakaan lain menjelaskan bahwa kecemasan merupakan rasa khawatir dan takut yang tidak jelas penyebabnya (Wulansari, 2017). Saat cemas, akan muncul imajinasi dalam pikiran seseorang yang akan semakin memperburuk kecemasan (Deswita and Wahyuni, 2013). Preeklampsia merupakan salah satu kondisi kehamilan resiko tinggi, sehingga memungkinkan ibu mengalami kecemsan.

Efek negatif kecemasan dapat terjadi pada fisik maupun psikologis. Efek fisik diantaranya tubuh menggigil, keringat berlebih, jantung berdebar, sakit kepala, gelisah, tangan gemetar, otot menegang, lambung terasa mual, tubuh terasa lemas, kemampuan berproduktivitas berkurang. Efek psikis diantaranya perasaan tegang, bingung, khawatir, susah berkonsentrasi, perasaan tidak menentu (Wulansari, 2017).
Sedangkan efek negatif kecemasan pada kehamilan diantaranya meningkatkan resiko kelahiran prematur, keguguran, kelahiran dengan berat badan rendah, dan menyebabkan bayi dirawat di ruang perawatan khusus. Bayi yang dilahirkan dari ibu yang mengalami kecemasan pada saat hamil dapat menunjukkan gejala perkembangan yang lebih rendah, lebih bermasalah dengan makan dan tidur, lebih kurang berinteraksi dengan ibu bahkan kecemasan tersebut dapat diwarisi oleh anak sampai dewasa. Kecemasan juga dapat meningkatkan resiko hipertensi pada kehamilan (Deswita and Wahyuni, 2013), sehingga kecemasan pada ibu preeklampsia akan semakin meningkatkan tekanan darah.

Beberapa penelitian yang melaporkan adanya penurunan skor kecemasan setelah mendapatkan terapi murottal menunujukkan bahwa terapi murottal cukup efektif untuk menurunkan kecemasan dan dapat digunakan sebagai pelengkap pengobatan medis. Hal tersebut sangat baik jika bisa diterapkan secara meluas termasuk pada ibu hamil dengan preeklampsia, mengingat ibu hamil dengan preeklampsia rentan mengalami kecemasan dan angka kejadian preeklampsia dari tahun ke tahun semakin meningkat, bahkan menjadi salah satu sebab dominan kematian Ibu.

Agama merupakan suatu keyakinan yang didalamnya terdapat sikap berserah diri terhadap Tuhan Yang Maha Tinggi. Sikap pasrah akan memunculkan sikap optimis pada diri seseorang sehingga timbul perasaan positif seperti rasa aman dan tidak cemas. Mendengarkan Al-Qur'an mengandung unsur kerohanian yang 
dapat membangkitkan keimanan, harapan dan rasa percaya diri seseorang yang sedang cemas, sehingga dapat mempercepat pemulihana dari kondisi cemas yang dirasakan (Deswita and Wahyuni, 2013). Mendengarkan murottal bagi ibu hamil preeklampsia dapat membangkitkan harapan agar kehamilan dapat berjalan normal, ibu dan bayi sehat selamat sampai bersalin.

Terapi murotal merupakan sebuah stimulan menggunakan AL-Qur'an yang didominasi gelombang delta daerah sentral dan frontal yang dapat memberikan rasa tenang dan nyaman bagi ibu hamil. Sel akan merangsang otak memproduksi zat kimia neuropeptide yang merupakan umpan balik kenikmatan dan kenyamanan (Nugraheni and Romdiyah, 2018).

Dari tabel 2 dapat kita lihat bahwa dari 8 artikel yang berkaitan dengan tema pengaruh terapi murottal terhadap tekanan darah ibu hamil preeklampsia, semuanya menggunakan desain pretestposttest, dimana 4 diantaranya menggunakan kelompok kontrol dan 4 yang lain tidak. Semua artikel (8) melaporkan bahwa terdapat pengaruh terapi murottal terhadap tekanan darah atau terdapat perbedaan tekanan darah sebelum dan sesudah mendapatkan perlakuan terapi murottal. Namun dari 8 artikel tersebut, perlakuan yang diberikan tidak hanya terapi murottal saja, namun ada beberapa yang menggunakan kombinasi dengan teknik yang lain. Satu artikel mengkombinasi dengan relaksasi benson (Pratiwi et al., 2015), dan satu artikel yang lain mengkombinasi dengan senam aerobic low impact (Hernawan et al., 2017).
Ada 6 artikel yang menghitung mean pretest dan posttest sistol dan diastol dengan hasil sebagai berikut : Tabel 3. Perbandingan mean sistol dan diastol pada pretest dan posttest

\begin{tabular}{llllll}
\hline $\begin{array}{l}\text { No } \\
\text { arti } \\
\text { kel }\end{array}$ & Pretest & & Postest & Ket \\
\hline 1 & 165 & 95 & 152 & 85 & Turun \\
2 & 165.5 & 91 & 147.9 & 87.3 & Turun \\
3 & 153 & 96 & 142 & 87 & Turun \\
4 & 148.6 & 83.8 & 140 & 77.1 & Turun \\
5 & 149.5 & 95 & 139 & 89 & Turun \\
6 & 151.9 & 90 & 139.4 & 85 & Turun \\
\hline
\end{tabular}

(Kartini et al., 2016, Pratiwi et al., 2015, Erlina and Raharjo, 2016, Widyastuti, 2015, Yudistiro, 2017, Hernawan et al., 2017)

Tabel 3 menunjukkan bahwa, dari ke 6 artikel, nilai rata-rata tekanan darah baik sistol maupun diastol mengalami penurunan setelah mendapatkan perlakuan.

Tabel 4. Besaran penurunan mean sistol diastol pada pretestposttest

\begin{tabular}{ccc}
\hline No artikel & Sistole & Diastole \\
\hline 1 & 13 & 10 \\
2 & 17.6 & 3.73 \\
3 & 11 & 6 \\
4 & 8.57 & 6.67 \\
5 & 10,5 & 6 \\
6 & 12.46 & 5 \\
\hline Rata-rata & 12.19 & 6.23 \\
\hline
\end{tabular}

Adapun besaran penurunan mean sistol pretestposttest tertinggi adalah 17.6 dan terrendah adalah 8.57 dengan rata-rata 12.19. Sedangkan besaran penurunan mean diastol tertinggi adalah 10 dan terendah adalah 3,73 dengan rata-rata 6.23. Dari hasil pengukuran sistol diastol pada waktu sebelum dan sesudah perlakuan tersebut, menunjukkan adanya pengaruh dari terapi murottal terhadap tekanan darah. 
Dua artikel melaporkan bahwa setelah mendapatkan perlakuan mayoritas tingkatan hipertensi responden turun. Satu artikel melaporkan bahwa tingkatan hipertensi turun dari mayoritas hipertensi berat menjadi mayoritas tanpa hipertensi/ normal, satu artikel yang lain melaporkan bahwa tingkatan hipertensi turun dari mayoritas hipertensi menjadi mayoritas pre hipertensi (Aini et al., 2018, Siswoyo et al., 2017).

Secara fisik, lantunan Al-Qur'an mengandung unsur suara manusia. Suara tersebut dapat menurunkan hormon stres dan mengaktifkan hormon endorfin, meningkatkan perasaan rileks, mengalihkan perhatian dari rasa takut, cemas, tegang, serta memperbaiki sistem kimia tubuh sehingga dapat menurunkan tekanan darah (Pratiwi et al., 2015). Sebuah penelitian melaporkan bahwa mendengarkan ayat suci Al-Qur'an terbukti memiliki pengaruh yang signifikan dalam menurunkan ketegangan pada urat syaraf reflektif, yang mana hasil tersebut tercatat dan terukur kuantitatif dan kualitatif oleh sebuah alat berbasis komputer (Aini et al., 2018).

Berkaitan dengan Murottal yang digunakan dalam memberikan intervensi, dari 13 artikel yang menjadi subyek literature review, 5 artikel menggunakan surah Ar-Rahman, sedangkan artikel yang lain tidak menjelaskan secara detil surah apa yang digunakan. Oleh karena itu, dalam studi kasus, yang dipilih sebagai instrumen adalah murottal Surah ArRahman.

Ar-Rahman memiliki arti Yang Maha Pemurah. Banyak pendapat yang mengatakan bahwa surat Ar-Rahman merupakan surat kasih sayang. Semua ayat dalam surat Ar-Rahman mempunyai karakter ayat pendek sehingga nyaman didengarkan dan dapat menimbulkan efek relaksasi bagi pendengar yang masih awam sekalipun (Pratiwi et al., 2015).

Sedangkan untuk durasi pemberian terapi murottal hanya 3 artikel yang menjelaskan dengan detil. Satu artikel memberikan terapi murottal selama \pm 10 menit (Pratiwi et al., 2015), satu artikel memberikannnya selama 15 menit selama 1 minggu (Aini et al., 2018) dan 1 artikel lagi memberikan selama \pm 25 menit (Wulansari, 2017). Dalam studi kasus peneliti memutuskan untuk memilih salah satu durasi yang akan digunakan untuk memberikan intervensi, yaitu selama 15 menit dalam 7 hari.

\section{Studi Kasus}

Responden studi kasus ini sejumlah 2 orang, yaitu $\mathrm{Ny} \mathrm{M}$ dan $\mathrm{Ny}$ KL. Pendataan hari pertama pada $\mathrm{Ny} \mathrm{M}$ dilaksanakan pada tanggal 12 Juli 2018, dimana Ny M berusia 30 tahun, G2P1A0, hamil $18^{+1}$ minggu dan TD 140/70 mmHg. Ny M terdeteksi preeklampsia pada usia kehamilan $10^{+}$ 5 minggu dengan TD 130/80 $\mathrm{mmHg}$ dan protein urin +1 sehingga diagnosa yang dapat ditegakkan adalah ibu hamil dengan preeklapmsia superimposed. Selama antenatal care, tercatat TD tertinggi $\mathrm{Ny} \mathrm{M}$ adalah 140/90 mmHg.

Sebelum hamil Ny $\mathrm{M}$ mengatakan tidak memiliki riwayat hipertensi, namun pada saat bidan desa melaksanakan kegiatan PISPK (Program Indonesia Sehat dengan Pendekatan Keluarga) tanggal 5 maret 2018 diperoleh hasil TD 170/120 $\mathrm{mmHg}$, kemungkinan pembuahan baru terjadi 2-3 minggu setelah tanggal 
tersebut, karena tanggal HPHT tanggal 7 maret 2018, sehingga bisa disimpulkan bahwa Ny $M$ sudah mengalami hipertensi sebelum kehamilan, namun tidak mengetahuinya. Dalam kepustakaan, preeklampsia superimposed adalah ibu hamil yang menderita hipertensi sebelum kehamilan 20 minggu namun disertai dengan tanda-tanda preeklampsia (Saifuddin, 2009).

Pada hari pertama wajah $\mathrm{Ny} \mathrm{M}$ tampak tegang, belum mau memejamkan mata pada saat mendengarngarkan murottal dan belum bisa mendengarkan murottal dengan rileks, namun pada hari berikutnya $\mathrm{Ny}$ M tampak lebih rileks. Pada hari pertama tersebut peneliti mengkaji perasaan Ny $\mathrm{M}$ terkait kondisi yang sedang dialami. Ny $M$ mengatakan cemas, kenapa kehamilannya yang kedua ini tekanan darahnya tinggi, padahal kehamilan sebelumnya normal bahkan belum pernah menderita hipertensi. Ny M merasa cemas setiap kali didatangi bidan atau kontrol dengan dokter SpOG di rumah sakit, karena merasa takut akan dilakukan suatu tindakan tertentu serta pengalaman merasa mendapat pertanyaan dan pernyataan yang kurang menyenangkan dari dokter. Ny $M$ merasa bingung apa yang menjadi penyebab tekanan darahnya tinggi? Kenapa tekanan darahnya tinggi namun tetap diberikan tablet penambah darah? Ny M menyadari bahwa dirinya tergolong orang yang sensitif, termasuk terhadap pembicaraan orang sekitarnya tentang kondisi kehamilannya saat ini.

Peneliti mendampingi Ny $\mathrm{M}$ mendengarkan murottal selama 3 hari di awal, setelah dirasa responden sudah dapat mendengarkan dengan rileks, maka hari berikutnya peneliti tidak mendampinginya lagi dan baru datang pada hari ke 7. Ny M menceritakan bahwa sejak hari ke 4, dia mendengarkan murottal pada malam hari menjelang tidur. Kesan yang diberikan setelah mendapatkan terapi murottal selama 7 hari adalah merasa lebih tenang, tidak terlalu memikirkan tekanan darah dan tidak terlalu peduli dengan pembicaraan orang tentang kondisinya.

Sedangkan pendataan hari pertama pada Ny KL dilaksanakan pada tanggal 13 Juli 2018, dimana Ny KL berusia 26 tahun, G1P0A0, hamil $30^{+3}$ minggu dan TD 130/90 mmHg. Ny KL terdeteksi preeklampsia pada usia kehamilan 27 minggu dengan TD $130 / 80 \mathrm{mmHg}$ dan protein urin +1 sehingga diagnosanya adalah ibu hamil dengan preeklampsia. Sesuai kepustakaan bahwa diagnosis preeklampsia dapat ditegakkan jika ditemukan tanda TD $\geq 140 / 90 \mathrm{mmHg}$ dan disertai minimal salah satu tanda yaitu proteinurin, trombositopenia, gangguan ginjal, gangguan liver, edema paru, gejala neurologis dan gangguan sirkulasi uteroplasenter (Noroyono and dkk, 2016).

Sebelum hamil Ny KL tidak memiliki riwayat hipertensi dan tidak ada riwayat keluarga yang hipertensi, namun sebelum hamil $\mathrm{Ny} \mathrm{KL}$ tergolong obesitas, yaitu dengan IMT 35,66 (BB 89, TB 158). Ny KL juga memiliki riwayat infertilitas selama 4,5 tahun. Sejak hari pertama wajah Ny KL tampak rileks, dia menyatakan bahwa tidak terlalu memikirkan tekanan darah yang tergolong agak tinggi, dan berserah diri pada Tuhan Yang Maha Kuasa, semoga kehamilannya berlangsung sehat. Sejak hari ke 2 peneliti tidak lagi 
mendampingi $\mathrm{Ny}$ KL pada saat mendengarkan murottal, namun Ny KL tetap mendengarkan murottal sehari 2 kali yaitu pagi dan sore hari. Kesan yang disampaiakan Ny KL setelah mendengarkan murottal selama 7 hari adalah merasa nyaman dan "adem" (tenang).

Kedua responden sama-sama memiliki faktor risiko preeklampsia, faktor risiko pada $\mathrm{Ny} \mathrm{M}$ adalah riwayat hipertensi sedangkan pada $\mathrm{Ny}$ KL adalah obesitas dan primigravida. Tekanan darah sebelum hamil pada $\mathrm{Ny}$ $M$ adalah 170/120 mmHg, dalam kepustakaan disebutkan bahwa diastolik > $80 \mathrm{mmHg}$ dan sistolik > $130 \mathrm{mmHg}$ merupakan faktor risiko superimposed preeklampsia. Hasil penelitian menunjukkan bahwa ibu dengan hipertensi kronik $22 \%$ mengalami superimposed preeklampsia (Noroyono and dkk, 2016). Penelitian lain melaporkan bahwa riwayat hipertensi adalah faktor yang paling banyak ditemukan sebagai faktor predisposisi preeklampsia (Magdalena and Historyati, 2014).

Nullipara dan obesitas merupakan faktor risiko preeklampsia yang masuk dalam kategori sedang (Noroyono and $\mathrm{dkk}$, 2016). Sebelum hamil indeks masa tubuh (IMT) $\mathrm{Ny}$ KL adalah 35,66, padahal nilai normal IMT adalah $18,5-24,9$, dan nilai IMT 25 29,9 sudah masuk kategori kelebihan berat badan, sedangkan IMT > 30 tergolong obesitas. Semakin besar IMT wanita semakin meningkatkan risiko preeklampsia pada masa kehamilan. Hasil penelitian menunjukkan bahwa ibu hamil dengan IMT > 35, 4 kali lipat berisiko menderita preeklampsia, sedangkan nulllipara berisiko 3 kali lipat menderita preeklampsia (Noroyono and dkk, 2016). Penelitian lain melaporkan bahwa ibu hamil primigravida berisiko 5,594 kali lipat mengalami komplikasi preeklampsia, sedangkan ibu hamil dengan obesitas sebelum kehamilan berisiko 5,632 kali lipat (Nur and Arifuddin, 2017).

Ibu hamil primigravida sering kali mengalami stres menghadapi persalinan, sehingga meningkatkan kadar kortisol dalam darah. Tingginya kadar kortisol tersebut mengakibatkan tubuh mempersiapkan diri untuk merespon terhadap semua stressor termasuk meningkatkan curah jantung dan mempertahankan tekanan darah.

Obesitas merupakan penimbunan lemak berlebihan didalam tubuh, yang mana hal tersebut dapat mengakibatakan timbulnya berbagai penyakit. Pada kasus Obesitas, resistensi leptin di tubuh menyebabkan perubahan hormonal, metabolik, neurologi dan hemodinamik sehingga terjadi hipertensi (Nur and Arifuddin, 2017).

Tabel 5 skor kecemasan sebelum dan sesudah terapi murottal

\begin{tabular}{|c|c|c|c|c|c|}
\hline $\mathrm{N}$ & Nama & Sebel & & Sesuda & \\
\hline O & $\begin{array}{l}\text { Respo } \\
\text { nden }\end{array}$ & $\begin{array}{l}\text { Skor } \\
\text { Kece } \\
\text { masa } \\
\mathrm{n}\end{array}$ & $\begin{array}{l}\text { Katego } \\
\text { ri } \\
\text { kecema } \\
\text { san }\end{array}$ & $\begin{array}{l}\text { Skor } \\
\text { Kece } \\
\text { masan }\end{array}$ & $\begin{array}{l}\text { Kateg } \\
\text { ori } \\
\text { kece } \\
\text { masa } \\
\mathrm{n}\end{array}$ \\
\hline 1 & $\begin{array}{l}\text { Ny. } \\
\text { M }\end{array}$ & 31 & Cemas & 12 & $\begin{array}{l}\text { Tidak } \\
\text { cemas }\end{array}$ \\
\hline 2 & $\begin{array}{l}\text { Ny. } \\
\text { KL }\end{array}$ & 21 & $\begin{array}{l}\text { Tidak } \\
\text { cemas }\end{array}$ & 19 & $\begin{array}{l}\text { Tidak } \\
\text { cemas }\end{array}$ \\
\hline
\end{tabular}

Tabel 5 dapat diinterpretasikan bahwa kedua responden sama-sama mengalami penurunan skor kecemasan. Pada Ny M skor kecemasan turun cukup drastis, yaitu sebanyak 19 poin, sedangkan Ny KL sebanyak 2 poin. Ny $\mathrm{M}$ mengalami penurunan status kecemasan dari cemas menjadi tidak cemas. 
Kedua responden penelitian adalah ibu hamil dengan preeklampsia, namun hanya $\mathrm{Ny} M$ yang mengalami kecemasan sedangkan Ny KL tidak. Kecemasan yang dialami Ny M sesuai dengan hasil penelitian yang melaporkan bahwa ibu dengan preeklampsia mayoritas memiliki kecemasan dalam kategori sedang dan berat (Trisiani, 2016). Penelitian lain menyebutkan bahwa ada perbedaan skor kecemasan antara ibu hamil dengan preeklampsia dibandingkan dengan ibu hamil normal, dimana skor kecemasan ibu hamil preeklampsia (dengan rata-rata 30,45) lebih tinggi dibandingkan dengan ibu hamil normal. Wanita yang mengalami komplikasi selama kehamilan berisiko tinggi untuk terjadinya kecemasan atau depresi, salah satunya adalah preeklampsia (Serudji et al., 2017). Kecemasan merupakan unsur kejiwaan yang menggambarkan perasaan dan keadaan emosional saat menghadapi kenyataan atau kejadian dalam hidupnya. Hal tersebut dapat menyebabkan spasme pembuluh darah memburuk sehingga terjadi kenaikan tekanan darah (Trisiani, 2016). Preeklampsia merupakan suatu kasus patologi dalam kehamilan, sehingga wajar jika ibu hamil dengan preeklampsia merasa cemas dengan kondisinya. Oleh karena itu kecemasan pada ibu hamil preeklampsia harus dikelola dengan baik agar tekanan darah cenderung stabil dan tidak semakin meningkat, sehingga kesejahteraan ibu dan janin terjamin dengan baik.

Kecemasan yang di alami Ny $\mathrm{M}$ diperberat dengan kurangnya informasi tentang kondisi yang dialami saat ini, terbukti dengan banyaknya pertanyaan terkait kehamilan dengan preeklampsia yang dia ajukan. Sebuah penelitian menyatakan bahwa pengetahuan yang kurang berhubungan dengan kecemasan pada ibu hamil primi gravida dalam berhubungan seksual. Dalam kepustakaan disebutkan bahwa pengetahuan yang rendah menyebabkan seseorang lebih mudah mengalami stress. Ketidaktahuan terhadap suatu hal merupakan sebuah tekanan tersendiri yang dapat mengakibatkan krisis dan menimbulkan kecemasan. Kurang informasi menyebabkan tingkat pengetahuan seseorang kurang, yang kemudian dapat memicu terjadinya stress dan kecemasan (Mubasyiroh, 2013). Pemahaman seseorang terhadap suatu kerangka berfikir yang jelas akan menurunkan kecemasan bahkan sampai pada kondisi yang sedang atau ringan (Arifah and Trise, 2012).

Kecemasan yang dialami Ny M juga diperberat oleh pertanyaan dan pernyataan dokter SpOG di RS yang dirasa kurang nyaman ketika menyampaikan hasil pemeriksaan dan memberikan edukasi. Hal tersebut menjadikan Ny $M$ merasa takut setiap kali kontrol di RS dan merasa enggan untuk kontrol kembali ke RS. Komunikasi antara tenaga kesehatan dengan pasien merupakan salah satu unsur penting dalam keberhasilan terapeutik. Beberapa hasil penelitian mengemukakan hubungan antara komunikasi terapeutik dengan kecemasan, diantanya salah satu penelitian melaporkan bahwa adanya pengaruh komunikasi terapeutik terhadap tingkat kecemasan ibu dalam menghadapi proses persalinan kala I di RS (Wildan and Palupi, 2016), penelitian lain menjelaskan bahwa pemberian informasi tentang persiapan operasi melalui pendekatan 
komunikasi terapeutik berpengaruh dalam menurunkan kecemasan pasien (Arifah and Trise, 2012). Komunikasi terapeutik merupakan suatu bentuk komunikasi yang direncanakan secara sadar, yang memiliki tujuan dan dipusatkan untuk kesembuhan pasien. Komunikasi terapeutik juga merupakan kemampuan atau keterampilan tenaga kesehatan untuk membantu pasien beradaptasi dengan stres, mengatasi gangguan psikologis, dan belajar bagaimana berhubungan dengan orang lain (Yusnita, 2012). Oleh karena itu tenaga kesehatan yang berhubungan dengan ibu hamil seharusnya dapat menjaga kualitas komunikasi terapeutik demi tujuan kesembuhan pasien, tidak hanya tentang apa yang dijelaskan dan apa yang ditanyakan, namun mencakup bagaimana cara berkomunikasi sehingga informasi yang disampaiakan ke pasien dapat diterima dengan baik namun tidak menyebabkan stres atau cemas.

Sedangkan kondisi Ny KL yang tidak mengalami kecemasan walaupun menderita preeklampsia selama kehamilan kemungkinan dikarenakan psikologi Ny KL yang lebih stabil dan telah beradaptasi dengan kondisi saat ini. Hal tersebut tercermin dari raut wajah yang santai dan perkataan yang menggambarkan bahwa dia rileks menghadapi kondisi ini sejak kunjungan pertama peneliti.

Kondisi psikologis yang stabil dan tidak mengalami kecemasan pada $\mathrm{Ny}$ KL kemungkinan karena taraf pendidikan Ny KL lebih tinggi, yaitu lulusan SMA sedangkan Ny M lulusan SMP. Selain itu Ny KL juga terlihat memiliki gadged sehingga akses informasi lebih luas. Pada hari ke $2 \mathrm{Ny}$ KL mengatakan bahwa semalam sudah browshing murottal Surah Ar-Rahman di Internet, namun belum menemukan seperti yang diperdengarkan oleh peneliti di hari pertama. Hal tersebut menunjukkan antusiasme dan kecakapan responden dalam mencari informasi di dunia maya. Dengan informasi yang lebih luas, membuat Ny KL lebih adaptif dengan kondisi kehamilan yang disertai preeklampsia, sehingga tidak mengalami kecemsan. Hasil penelitian menyebutkan bahwa ada hubungan antara pendidikan dengan tingkat kecemasan ibu menjelang persalinan. Dalam sebuah kepustakaan dijelaskan bahwa tingkat pendidikan yang lebih tinggi akan semakin memperluas pandangan dan lingkup pergaulan, sehingga mempermudah responden untuk menerima informasi tentang kesehatan yang kemudian akan menurunkan tingkat kecemasan. Kepustakaan lain menyatakan bahwa semakin tinggi tingkat pendidikan seseorang dimana seseorang akan dapat mencari atau menerima informasi dengan baik sehingga lebih cepat mengerti akan kondisi dan keparahan penyakit yang diderita dan akan berpengaruh terhadap kecemasan pada orang tersebut (Handayani, 2017).

Tabel 6 tekanan darah sebelum dan sesudah terapi murottal

\begin{tabular}{|c|c|c|c|c|}
\hline \multirow{2}{*}{$\begin{array}{l}\mathrm{N} \\
\mathrm{O}\end{array}$} & \multirow{2}{*}{$\begin{array}{l}\text { Nama } \\
\text { responde } \\
\mathrm{n}\end{array}$} & \multicolumn{3}{|l|}{ Tekanan darah } \\
\hline & & $\mathrm{Hr} 2$ & Hr 3 & $\mathrm{Hr} 7$ \\
\hline 1 & Ny M & $140 / 90 \quad 125 / 90$ & $110 / 85$ & $120 / 80$ \\
\hline 2 & Ny. KL & $130 / 80 \quad 120 / 85$ & $130 / 90$ & $120 / 80$ \\
\hline
\end{tabular}

Tabel 6 dapat diinterpretasikan bahwa TD responden dari hari pertama sampai hari ke 7 cenderung mengalami penurunan. Penurunan TD lebih terlihat nyata pada Ny M, dimana diastolik semakin turun menuju batas normal. Sedangkan pada $\mathrm{Ny} \mathrm{KL}$ 
tekanan darah cenderung naik turun, termasuk tekanan diastoliknya.

Skor kecemasan responden setelah mendapatkan terapi murottal keduanya mengalami penurunan. Bahkan skor kecemasan Ny M turun sangat drastis, yaitu sebesar $38 \%$ dan pindah dari kategori cemas menjadi tidak cemas. Hal ini sesuai dengan penelitian yang menyatakan bahwa tingkat kecemasan pada ibu bersalin menunjukkan adanya penurunan sesudah dilakukan terapi murottal. Dengan terapi murotal kualitas kesadaran seseorang terhadap Tuhan akan meningkat, baik orang tersebut tahu arti Al-Quran atau tidak. Kesadaran tersebut akan menyebabkan totalitas kepasrahan kepada Allah SWT, dalam keadaan ini otak berada pada gelombang alpha, yang dapat menyingkirkan stres dan menurunkan kecemasan. Dalam keadaan tenang otak dapat berpikir dengan jernih dan dapat melakukan perenungan tentang adanya Tuhan, sehingga terbentuk koping atau harapan positif pada pasien (Handayani et al., 2014). Sebuah penelitian melaporkan bahwa mendengarkan dan membacaAl-Qur'an dapat menyebabkanpeningkatan dominan gelombang otak beta,alpha dan theta(Astuti et al., 2017).

Murottal mampu memacu sistem saraf parasimpatis yang mempunyai efek berlawanan dengan sistem saraf simpatis, sehingga terjadi keseimbangan pada kedua sistem saraf autonom yang menjadi prinsip dasar dari timbulnya respon relaksasi (Handayani et al., 2014). Beberapa fungsi dari saraf parasimpatis diantaranya adalah mempersarafi jantung dan memperlambat denyut jantung. Sedangkan rangsangan saraf otonom yang terkendali akan menyebabkan sekresi epinefrin dan norepinefrin sehingga menghambat pembentukan angiotensin yang kemudian dapat menurunkan tekanan darah (Pratiwi et al., 2015).

Terapi murottal dalam studi kasus menggunakan surah Ar-Rahman dan diberikan selama 15 menit setiap hari sampai hari ke 7 (tujuh). Dalam kepustakaan disebutkan bahwa mendengarkan terapi murottal selama 10-15 menit dapat memberikan efek terapeutik. Musik dari alunan Al Qu'an akan menghasilkan perubahan status kesadaran melalui bunyi, kesunyian, ruang dan waktu (Karyati, 2016). Terapi murottal tergolong dalam jenis terapi nonfarmakologi, yaitu terapi komplementer (pelengkap). Terapi Murottal Surah Ar- Rahman ini menjadi salah satu terapi yang aman, tanpa efek samping, murah dan mudah dilakukan (Widyastuti, 2015).

TD pada kedua responden cenderung mengalami penurunan dari hari pertama ke hari ke tujuh. Ny M dari 140/90 mmHg menjadi $125 / 80$ mmHg, sedangkan Ny KL turun dari $130 / 80 \mathrm{mmHg}$ menjadi $120 / 80 \mathrm{mmHg}$. Hal ini sesuai hasil penelitian yang menyebutkan bahwa ada pengaruh mendengarkan murrotal terhadap penurunan tekanan darah diastolik pada ibu hamil preeklamsi (Kartini et al., 2017). Tekanan diastolik Ny KL tetap dan masih dalam kategori normal. Sedangkan sistolik untuk kedua responden sama-sama mengalami penurunan. Membaca Al-Qur'an atau mendengarkan murottal akan memberikan perubahan arus listrik di otot, perubahan sirkulasi darah, perubahan detak jantung dan perubahan kadar darah pada kulit.

Mendengarkan murottal Al-Qur'an mengandung unsur meditasi, autosugesti dan relaksasi yang akan 
memberikan efek ketenangan dalam tubuh. Rasa tersebut kemudian akan memberikan respon emosi positif yang sangat berpengaruh dalam mendatangkan persepsi positif (Pratiwi et al., 2015). Persepsi positif yang timbul akan meransang hipotalamus untuk menurunkan hormon stress dan mengaktifkan hormon endorfin sehingga meningkatkan perasaan rileks dan mengalihkan perhatian dari perasaan takut, cemas dan tegang serta memperbaiki sistem kimia tubuh sehingga memperlambat pernafasan, detak jantung, denyut nadi, aktivitas gelombang otak dan menurunkan tekanan darah (Kartini et al., 2017).

Penurunan tekanan darah dan kecemasan pada ibu hamil preeklapmsia setelah diberikan terapi menunjukkan kemanfaatan dari terapi murottal Al-Qur'an Surah ArRahman. Dan hasil tersebut sesuai dengan kesimpulan dari literature review bahwa terdapat penurunan skor kecemasan sebelum dan sesudah perlakuan serta terdapat perbedaan tekanan darah sebelum dan sesudah mendapatkan perlakuan.

Terapi murottal bukanlah terapi medis yang dapat menyembuhkan preeklampsia, namun dapat menjadikan ibu hamil lebih tenang dan rileks sehingga mengurangi kecemasan terhadap kondisinya. Kecemasan yang berlarut-larut dapat berbahaya bagi ibu hamil dengan preeklampsia, karena dapat memperberat kondisi preeklampsia, diantaranya tekanan darah semakin tinggi, gangguan organ yang semakin bertambah ataupun sampai pada eklampsia dan kematian.

\section{Simpulan}

Simpulan yang dapat diambil dari literature review adalah (1) terdapat penurunan skor kecemasan sebelum dan sesudah perlakuan (ada pengaruh murottal terhadap kecemasan) dengan mean penurunan skor kecemasan 6,297, (2) terdapat pengaruh terapi murottal terhadap tekanan darah atau terdapat perbedaan tekanan darah sebelum dan sesudah mendapatkan perlakuan, rata-rata penurunan mean sistol 12,188 dan rata-rata penurunan mean diastol 6,233. Sedangkan simpulan yang dapat diambil dari studi kasus adalah (1) Karakteristik responden yang menjadi faktor risiko terjadinya preeklampsia adalah riwayat hipertensi, obesitas dan nullipara, (2) hal yang memperberat kecemasan diantaranya kurangnya pengetahuan/informasi serta komunikasi terapeutik yang kurang optimal dan (3) Skor kecemasan turun setelah diberikan terapi murottal selama 7 hari, TD juga relatif turun. Dari simpulan tersebut penulis berkeinginan untuk melanjutkan penelitian ke tahap yang lebih lanjut, yaitu penelitian dengan responden yang mencukupi untuk dilakukan uji statistik serta penelitian untuk mendapatkan data yang lebih obyektif dari variabel kecemasan, misalnya saja dengan uji hormonal.

Saran yang dapat diberikan adalah tenaga kesehatan dan masyarakat dapat menggunakan terapi murottal sebagai salah satu alternatif metode relaksasi untuk mengurangi kecemasan pada ibu hamil dengan preeklampsia, juga bisa di terapkan pada pelayanan kebidanan secara umum, yaitu pada ibu hamil, bersalin atau nifas. 


\section{Daftar pustaka}

AINI, D. N., WULANDARI, P. \& ASTUTI, S. P. 2018. Pengaruh Terapi Murottal Al-Qur'an Terhadap Tekanandarah Pada Pasien Hipertensi di Ruang Cempaka RSUD Dr. H. Soewondo Kendal. Jurnal Ners Widya Husada Semarang, 3.

ARIFAH, S. \& TRISE, I. N. 2012. Pengaruh Pemberian Informasi Tentang Persiapan Operasi Dengan Pendekatan Komunikasi Terapeutik Terhadap Tingkat Kecemasan Pasien Pre Operasi di Ruang Bougenville RSUD Sleman. Jurnal Kebidanan, 4.

ASGHARI, E., FARAMARZI, M. \& MOHAMMMADI, A. K. 2016. The Effect of Cognitive Behavioural Therapy on Anxiety, Depression and Stress in Women with Preeclampsia. Journal of Clinical \& Diagnostic Research, $10,4-7$.

ASTUTI, A., SURYONO, S., WIDYAWATI, M. N., SUWONDO, A. \& MARDIYONO, M. 2017. Effect Of Audio Therapy Using AlQur'an Murrotal On Behavior Development In Children With Autism. Belitung Nursing Journal, 3, 470-477.

DESWITA \& WAHYUNI, R. 2013. Pengaruh Terapi Murotal Terhadap Tingkat Kecemasan Menghadapi Persalinan Pada Ibu Hamil di Wilayah Kerja Puskesmas Andalas. NERS Jurnal Keperawatan, 9, 116-126.

ERLINA \& RAHARJO, S. B. 2016. Terapi Murottal Surat Ar-Rahman Terhadap Perubahan Tekanan Darah Pasien Hipertensi Di RSUDZA Banda Aceh. Jurnal Ilmiah Mahasiswa Fakultas Keperawatan, 1.
HANDAYANI, R. 2017. Faktor-Faktor Yang Berhubungan Dengan Tingkat Kecemasan Menjelang Persalinan Pada Ibu Primigravida Trimester III di Wilayah Kerja Puskesmas Lubuk Buaya Padang Tahun 2012. Ners Jurnal Keperawatan, 11, 60-69.

HANDAYANI, R., FAJARSARI, D., TRISNA ASIH, D. R. \& ROHMAH, D. N. 2014. Pengaruh terapi murottal Al-Qur'an untuk penurunan nyeri persalinan dan kecemasan pada ibu bersalin kala I Fase Aktif. Bidan Prada: Jurnal Publikasi Kebidanan Akbid YLPP Purwokerto, 5.

HERNAWAN, A. D., ALAMSYAH, D. \& SARI, M. M. 2017. Efektivitas Kombinasi Senam Aerobik Low Impact Dan Terapi Murottal Quran Terhadap Perubahan Tekanan Darah Pada Lansia Hipertensi Di UPT Panti Sosial Tresna Werdha Mulia Dharma Kabupaten Kubu Raya. JUMANTIK (Jurnal Mahasiswa dan Peneliti Kesehatan), 4, 1-15.

ISWORO, A., HAKIMI, M. \& WIBOWO, T. 2012. Hubungan antara Kecemasan dengan Kejadian Preeklampsia Di Kabupaten Banyumas Jawa Tengah. Berita Kedokteran Masyarakat (BKM), $28,9$.

KARTINI, K., FRATIDHINA, Y. \& KURNIYATI, H. 2016. Pengaruh Mendengarkan Murottal Terhadap Penurunan Tekanan Darah Pada Ibu Hamil Preeklamsi Di RSIA PKU Muhammadiyah Tangerang. Jurnal JKFT, 2, 40-50.

KARTINI, K., FRATIDHINA, Y. \& KURNIYATI, H. 2017. Pengaruh Mendengarkan Murottal Terhadap Penurunan Tekanan Darah Pada Ibu Hamil Preeklamsi Di Rsia Pku Muhammadiyah Tangerang. Jurnal JKFT, 2, 40-50. 
KARYATI， S. 2016. Aplikasi Terapi Murotal Al-Qur'An Dan Komunikasi Terapeutik Sebagai Upaya Menurunkan Tingkat Kecemasan Persalinan. The 4 th Univesity Research Coloquium, 175-182.

KEMENKES 2015. Kesehatan Dalam Kerangka Sustainable Development Goal's (SDG's). Jakarta: Dirjen Bina Gizi KIA KEMENKES RI.

KEMENKES 2016

KESEHATAN INDONESIA

TAHUN 2015. In: RI, K. (ed.). JAKARTA: KEMENKES RI.

LAILI, F. \& WARTINI, E. 2017. The Influence of Combination Murottal Holy Qur'an And Deep Breath Relaxation To Face Anxiety A Labor. The 1st International Conference Ikatan Perawat Maternitas East Java 2017 (Ich_Ipemi). Interdiciplinary Innovation And Intervention In Health To Achieve The Suistinable Development Goal's (SDG's), 1-8, 70-76.

MAGDALENA, M. \& HISTORYATI, D. 2014. Gambaran Faktor Penyebab Preeklampsia Pada Kehamilan Di Wilayah Kerja Puskesmas Tembelang Jombang.

MUBASYIROH, L. 2013. Hubungan Tingkat Pengetahuan dengan Kecemasan Ibu Hamil Primigravida tentang Hubungan Seksual selama Kehamilan di Puskesmas Kecamatan Jatibarang Kabupaten Brebes. JURNAL KOMUNIKASI KESEHATAN (Edisi 7), 4.

NOROYONO, W. \& DKK 2016. Pedoman Nasional Pelayanan Kedokteran Diagnosis Dan Tata Laksana Pre-Eklamsia, Jakarta, POGI.

NUGRAHENI, N. \& ROMDIYAH, R. 2018. Perbedaan Perlakuan Senam Hamil Dan Terapi Murotal
Terhadap Tingkat Kecemasan Ibu Hamil Trimester III. Jurnal Penelitian dan Pengabdian kepada Masyarakat UNSIQ, 5.

NUR, A. F. \& ARIFUDDIN, A. 2017. Faktor Risiko Kejadian Preeklampsia Pada Ibu Hamil Di RSU Anutapura Kota Palu. Healthy Tadulako, 3, 69-75.

PRATIWI, L., HASNELI, Y. \& ERNAWATY, J. 2015. Pengaruh Teknik Relaksasi Benson Dan Murottal Al-qur'an Terhadap Tekanan Darah Pada Penderita Hipertensi Primer. Jurnal Online Mahasiswa Program Studi Ilmu Keperawatan Universitas Riau, 2, 1212-1220.

SAIFUDDIN, A. B. 2009. Buku Acuan Nasional Pelayanan Kesehatan Maternal Dan Neonatal,Jakarta, PT BPSP.

SERUDJI, J., UTOMO, Y. S. \& MACHMUD, R. 2017. Perbedaan Skor Kecemasan Taylor Minnesota Anxiety Scale (TMAS) Maternal Pada Kehamilan Dengan Preeklampsia Dan Hamil Normal. Andalas Obstetric And Gynecology Journal, 2.

SISWOYO, S., SETYOWATI, S. \& A'LA, M. Z. 2017. Pengaruh Terapi Murottal Al-Qur'an terhadap Tekanan Darah Pasien Pre Operasi Katarak dengan Hipertensi di Ruang Tulip Rumah Sakit Daerah dr. Soebandi Jember (The Effect of The Murottal Al-Qur'an Therapy on Blood Pressure of Pre Operative Cataract Patients with Hypertension in Tulip Inpatient Ward of dr. Soebandi Hospital, Jember). Pustaka Kesehatan, 5, 77-83.

TRISIANI, D. 2016. Hubungan Kecemasan Ibu Hamil terhadap Kejadian Preeklampsia. Jurnal Ilmiah Bidan, 1, 14-18.

WIDYASTUTI, I. W. 2015. Pengaruh Terapi Murottal Surah Ar-Rahman 
Terhadap Perubahan Tekanan

Darah Pada Lanjut Usia (Lansia)

Penderita Hipertensi Di Posyandu

Lansia Kenanga Wilayah Kerja

UPK Puskesmas Siantan Hulu

Kecamatan Pontianak Utara.

ProNers, 3.

WILDAN, M. \& PALUPI, J. 2016.

Pengaruh Komunikasi Terapeutik

Terhadap Tingkat Kecemasan Ibu

Dalam Menghadapi Proses

Persalinan Kala I. Jurnal

Penelitian Kesehatan" SUARA

FORIKES"(Journal of Health

Research" Forikes Voice"), 7, 103-107.

WULANSARI, A. 2017. Pengaruh Terapi

Murottal Terhadap Perubahan

Skor Kecemasan Ibu Bersalin

Kala I Fase Laten Di RS Nur Hidayah Bantul. Skripsi.

YUDISTIRO, R. E. 2017. Pengaruh

Terapi Suara Terhadap Tekanan

Darah Penderita Hipertensi Di

Posyandu Lansia Sedap Malam

Padukuhan Gandok Sleman Di

Yogyakarta. Skripsi.

YUSNITA, R. 2012. Hubungan

Komunikasi Teurapetik Bidan

Dengan Kecemasan Ibu Bersalin Di Ruang Kebidanan Dan Bersalin

Rumah Sakit Umum Daerah Kabupaten Pidie. Aceh: Jurnal Kesehatan Masyarakat. 